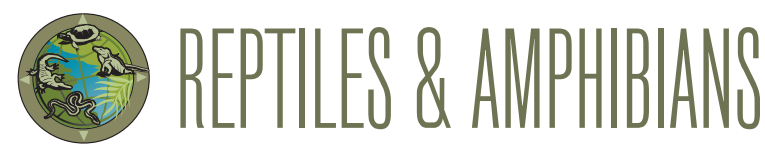

\title{
Predation by a Black Mussurana, Clelia clelia (Daudin 1803) (Serpentes: Dipsadidae), on an Andean Lancehead, Bothrocophias andianus (Amaral 1923), in Bolivia
}

Oliver Quinteros-Muñoz ${ }^{1}$ and Rodrigo Aguayo ${ }^{1,2}$

${ }^{1}$ Museo de Historia Natural Alcide d’Orbigny, Casilla 843, Cochabamba, Bolivia (ohlisin@gmail.com)

${ }^{2}$ Centro de Biodiversidad y Genética, Universidad Mayor de San Simón, Casilla 538, Cochabamba, Bolivia

$\mathrm{P}$ seudoboine snakes of the genus Clelia (Fitzinger 1826) range from Central America to southern Argentina (Zaher 1996; Giraudo 2001; Scott et al. 2006; Drummond et al. 2011). Two species, Clelia clelia (Daudin 1803) and Clelia langeri (Reichle and Embert 2005) have been recorded in Bolivia (Aguayo 2009; Reichle 2019).

The Black Mussurana (Clelia clelia) is a medium to large, mostly terrestrial snake distributed from Mexico to Argentina (Zaher 1996; Giraudo 2001; Giraudo and Scrocchi 2002; Scott et al. 2006; Alencar et al. 2013; Wallach et al. 2014). In Bolivia, it has been recorded in the departments of Beni, Cochabamba, Chuquisaca, La Paz, and Santa Cruz (Embert 2007). Like its congeners, C. clelia is opisthoglyphous and at least mildly venomous (Pinto et al. 1991; Silveira and Nishioka 1992). This species is considered a generalist and its diet includes small mammals, lizards, and snakes (Alencar et al. 2013; Gaiarsa et al. 2013), including pitvipers (CerdasFallas and Lomonte-Vigliotti 1982; Giraudo 2001; Pinto and Lemna 2002; Scott et al. 2006; Delia 2009). The Andean Lancehead (Bothrocophias andianus) is a terrestrial pitviper distributed in the Andean subtropical mountain forests of Peru and Bolivia (Campbell and Lamar 1989; Harvey et al. 2005).

At 0745 h on 26 August 2020, an adult Clelia clelia attacked an adult Andean Lancehead (Bothrocophias andianus) on an unpaved rural road $\left(17^{\circ} 23^{\prime} 49.80^{\prime \prime S}, 65^{\circ} 14^{\prime} 50.11^{\prime \prime W}\right.$; elev. 1,085 $\mathrm{m}$ asl) (Fig. 1). After immobilizing the prey by biting its head, the Black Mussurana appeared to suffocate the lancehead without constriction before ingesting the pitviper and moving into the nearby secondary forest. The entire sequence of attack, immobilization, and ingestion took about
2 hours. The sequence was very similar to that described by da Costa Pinto and de Lema (2002) for C. rustica, although the C. clelia did not constrict its prey, instead "imprisoning" it, as described by Rojas-Morales (2013) for C. equatoriana.

Local residents who observed this event readily identified both species, using the Quechua language names Illawi (= constrictor) for C. clelia and Qhilla (= lazy) for B. andianus. To the best of our knowledge, this is the first record of any species in the genus Bothrocophias as prey of C. clelia.

\section{Acknowledgements}

We thank the local residents for not disturbing and hurting the snakes, M. Zarate who provided the photographs, and T. Rainville for help with English.

\section{Literature Cited}

Aguayo, R. 2009. Reptiles de Bolivia. Bolivia Ecológica 53: 1-32.

Alencar, L.R., M.P. Gaiarsa, and M., Martins. 2013. The evolution of diet and microhabitat use in pseudoboine snakes. South American Journal of Herpetology 8: 60-66. https://doi.org/10.2994/SAJH-D-13-00005.1.

Cerdas-Fallas, L. and B. Lomonte-Vigliotti. 1982. Estudio de la capacidad ofiófaga y la resistencia de la zopilota (Clelia clelia, Colubridae) de Costa Rica a los venenos de serpiente. Toxicon 20: 936-939.

Campbell, J.A. and W.W. Lamar. 1989. The Venomous Reptiles of Latin America. Comstock Publishing Associates, Ithaca, New York, USA.

da Costa Pinto, C. and T. de Lema. 2002. Comportamento alimentar e dieta de serpentes, gêneros Boiruna e Clelia (Serpentes, Colubridae). Iheringia, Série Zoologia 92: 9-19. https://doi.org/10.1590/S0073-47212002000200002.

Delia, J. 2009. Another crotaline prey item of the Neotropical snake Clelia clelia (Daudin 1803). Herpetology Notes 2: 21-22.

Drummond, L., H. Costa, and M. Silvério Pires. 2011. Clelia plumbea (mussurana): Prey. Herpetological Bulletin 116: 37-38.

Embert, D. 2007. Distribution, diversity and conservation status of Bolivian reptiles. Unpublished doctoral dissertation, Mathematisch-Naturwissenschaftlichen Fakultät der Rheinischen Friedrich-Wilhelms-Universität, Bonn, Germany. 


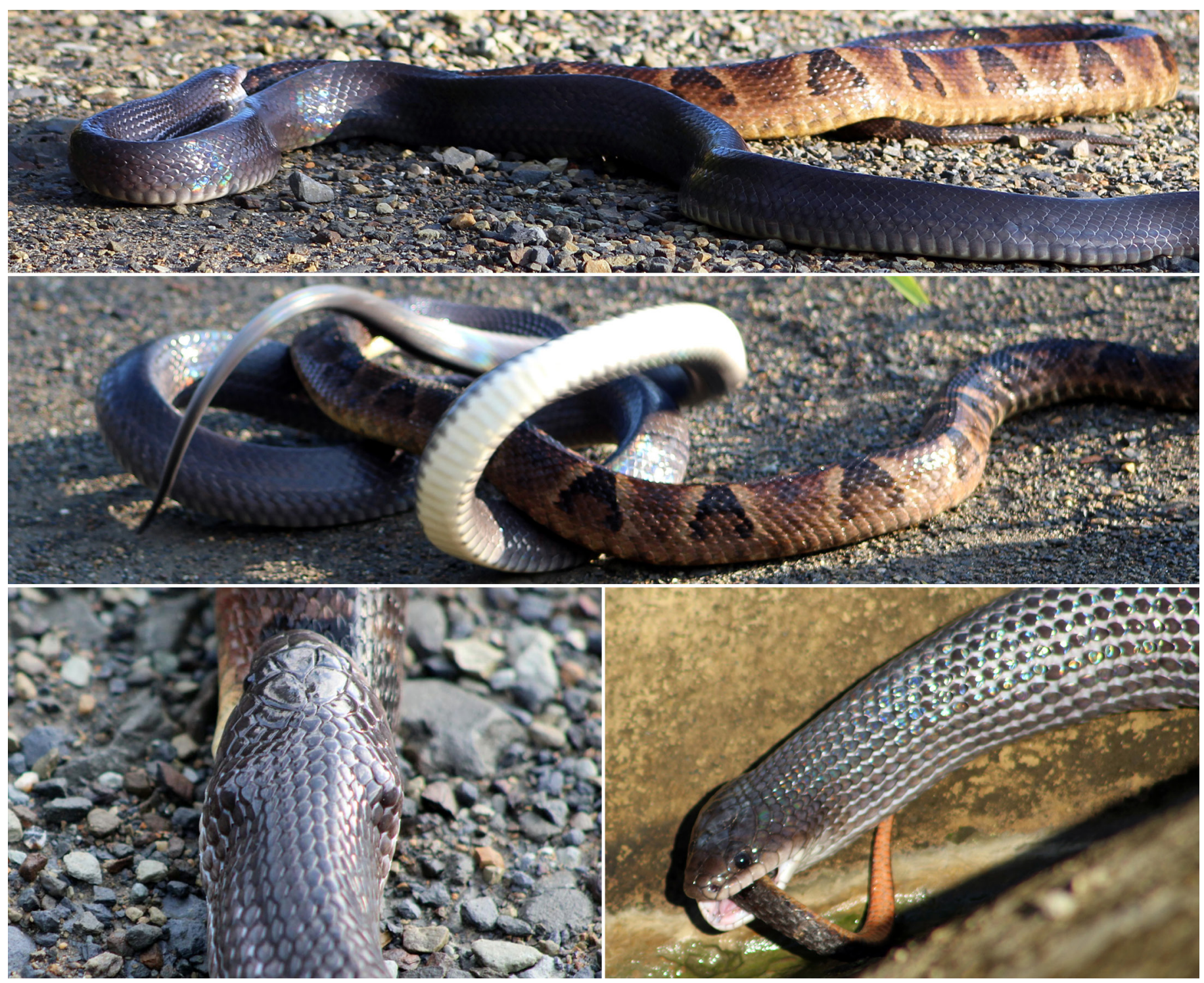

Fig. 1. Predation in nature by a Black Mussurana (Clelia clelia) on an Andean Lancehead (Bothrocophias andianus). Photographs by Modesto Zarate.

Gaiarsa, M.P., L.R. de Alencar, and M. Martins. 2013. Natural history of pseudoboine snakes. Papéis Avulsos de Zoologia 53: 261-283. https://doi.org/10.1590/ S0031-10492013001900001.

Giraudo, A. 2001. Serpientes de la Selva Paranaense y del Chaco Húmedo. Literature of Latin America, Buenos Aires, Argentina.

Giraudo, A. and G. Scrocchi. 2002. Argentinian snakes: An annotated checklist. Smithsonian Herpetological Information Service 132: 1-53.

Harvey, M.B., J. Aparicio, and L. Gonzales. 2005. Revision of the venomous snakes of Bolivia. II: the pitvipers (Serpentes: Viperidae). Annals of Carnegie Museum 74: 1-37. https://doi.org/10.2992/0097-4463(2005)74[1:ROTVSO]2.0.CO;2.

Pinto, R.N.L., Jr, N.J. da Silva, and S.D. Aird. 1991. Human envenomation by the South American opisthoglyph Clelia clelia plumbea (Wied). Toxicon 29: 1512-1516. https://doi.org/10.1016/0041-0101(91)90008-F.

Reichle, S. 2019. Serpientes de Bolivia. Bolivia Ecológica 87: 1-36.

Reichle, S. and D. Embert. 2005. New species of Clelia (Colubridae) from the Inter-Andean dry valleys of Bolivia. Journal of Herpetology 39: 379-383.
https://doi.org/10.1670/121-03A.1.

Rojas-Morales, J.A. 2013. Description of ophiophagy in Clelia equatoriana (Amaral, 1924) (Serpentes: Dipsadidae) in captivity. Herpetology Notes 6: 425-426.

Silveira, P.V.P. and S.D.A. Nishioka. 1992. Non-venomous snake bite and snake bite without envenoming in a Brazilian teaching hospital. Analysis of 91 cases. Revista-Instituto de Medicina Tropical de Sao Paulo 34: 499-499. https://doi. org/10.1590/s0036-46651992000600002.

Scott, N.J., Jr., A.R. Giraudo, G. Scrocchi, A.L. Aquino, P. Cacciali, and M. Motte. 2006. The genera Boiruna and Clelia (Serpentes: Pseudoboini) in Paraguay and Argentina. Papéis Avulsos de Zoologia 46: 77-105. https://doi. org/10.1590/S0031-10492006000900001.

Wallach, V., K.L. Williams, and J. Boundy. 2014. Snakes of the World: A Catalogue of Living and Extinct Species. CRC Press, Boca Raton, Florida, USA.

Zaher, H. 1996. A new genus and species of pseudoboine snake, with a revision of the genus Clelia (Serpentes, Xenodontinae). Bollettino del Museo Regionale di Scienze Naturali - Torino 14: 289-337. 